\title{
Type C Lymphomatoid Papulosis
}

National Cancer Institute

\section{Source}

National Cancer Institute. Type C Lymphomatoid Papulosis. NCI Thesaurus. Code C7199.

A variant of lymphomatoid papulosis characterized clinically by regressing skin papules,

and morphologically by features resembling anaplastic large cell lymphoma. 